THEMATIC ESSAY: ETHICS AND POLITICS

\title{
Pluralism, Social Work and an Ethical-Political Project: one theme many challenges
}

\author{
Valeria Lucilia Forti \\ Universidade Estadual do Rio de Janeiro (UERJ)
}

\section{Pluralism, Social Work and Ethical-Political Project: One theme, many challenges}

Abstract: This essay is the result of observations drawn from our decades of experience as a social worker and professor, particularly of classes in professional ethics in Social Work. It is also based on theoretical studies and qualitative empirical academic research about ethics/professional ethics and Social Work. The content was partially presented and debated in a lecture at the XV ENPESS. The arguments seek to deepen the debate about the relationship between pluralism and Social Work. Such a debate is essential to professionals in the field, since it is linked to the fundamental ethical principles of the current Code of Professional Ethics of Social Workers. It should be noted that there is a sufficient and critical apprehension of the subject by Social Work professionals and students must have an adequate and critical grasp of these issues, particularly considering the present moment when current conservative waves that are expressed with such importance in the social life of Brazilians and seem to have repercussions in this professional field.

Keywords: Pluralism. Social Work. Ethics. Conservatism. 


\section{Introduction}

Based on observations from our professional experience as a social worker and professor of social work, on theoretical studies and qualitative empiric academic research about ethics and professional ethics and social work, this article raises a debate that can be beneficial to the profession. The objective of this article is to contribute to the debate in the profession about this theme, considering what we believe to be relevant, suitable and essential in both a macro-societal sense and in the professional realm of social work. This time of a conservative retrocession in Brazilian social life in general, which seems to have important repercussions on our professional realm, generates concerns, challenges, conflicts and debates that strive to maintain respect for social conquests that Brazilians struggled to attain. For example we cite the Consolidated Labor Laws (CLT) of the Vargas era and the Constitution of 1988, which due to the time passed, should have had significant advances. Although it may not sound original, we are in a period of Brazilian history when "the obvious needs to be expressed". This is because of discourses and practices that obfuscate or seek to obfuscate reality, not expressing their goals and even denominating certain social phenomenon with distinction. This can have repercussions for social work, particularly if we consider the premises of the current critical professional project, because as we know, although they can be realized in different manners, professional projects are related to societary projects.

\section{Pluralism, its basic dimensions and pluralist values}

We begin with a synthetic reference to the pertinent teachings of professor Carlos Nelson Coutinho about pluralism. According to Coutinho (1991), pluralism is supported by two basic dimensions: 1) as a social and political phenomenon; 2) and as a reference in the construction of knowledge. Although we recognize the impertinence of separating these dimensions, the fulcrum of our approach is in the second dimension. Moreover, it should be clarified that pluralism is a phenomenon of the modern world, because, according to Coutinho, the Greek world did not know pluralism. In ancient Greece, there was no valorization of the private. The Greek democratic experience made possible the existence in Athens of a democratic order, at least for those considered citizens - excluding slaves, women and foreigners - but difference was not recognized as something positive, as something similar to what today we call pluralism. This is probably due to how the Greeks understood society and the citizen, that is, they emphasized the public realm in detriment to the private.

In modernity, with the rise of the bourgeoisie and the construction of the capitalist world, both the vision of man and society were altered, introducing an individualist vision of man, in which an exacerbated valorization of the individual became essential to the support for a production system based on free competition. Therefore, we find an important distinction between the ancient world and modernity. For example, the Greek emphasized the value of the polis, while in modernity there is an excessive valorization of the individual, based on the premise that individuals have inalienable natural rights in society, which is understood as the sum of individual interests, of private interests. In opposition to what was found in the ancient world, when individual differences were looked down on, in modernity individualism became valued and fundamental to the liberal concept of the world.

Thus, in modernity we are confronted with a defense of the private and the idea of institutional pluralism is considered necessary to limit power. This is because institutional pluralism is seen as a form of limiting power, by understanding that the way to limit one source of power is to create another. In modernity we also find the idea of defense of minorities. In the nineteenth century, the idea of the defense of a minority was seen as indispensable to face threats caused by the expansion of popular participation of workers. The concern for these threats sparked the hypothesis that the majority, until then seen as a fundamental parameter of liberal democracy, could become an oppressor of the interests of individualities and the liberties of minorities. This process, articulated to other aspects mentioned, gave origin to what according to Coutinho (1991), could be called pluralist values:

a) The conception of conflict as a positive value, that is, the consideration that difference and competition are positive factors;

b) The conception of tolerance as a positive value in face of various opinions, proposals and options;

c) The concept of the necessary division of powers as essential to preventing the formation of absolute power;

d) The conception of the right of minorities.

These four points refer to the bourgeois order and serve its expansion, they can also serve the expansion of human individuality. They are thus points that serve something that is characteristically incipient in social life today as when they arose. 
We can also observe that Rousseau, differently than most thinkers of his time, emphasized the public realm, displaying a modern line of thinking of a non-individualistic characteristic that focused on the perspective of the general will. Rousseau presented the idea of popular sovereignty, distinguishing the general will from common interest, because for Rousseau, the general will does not represent the idea of the will of everyone as a mere sum of individual wills. Nevertheless, despite the richness of the idea of collective will in Rousseau's thinking, he was critical of the possibility of political pluralism, and even denied the importance of particular/ private associations in society, which in the historic epoch that followed his work were essential to popular sovereignty. Thus, we highlight that the expansion of popular participation, which interfered in the formation of political will, was due to the creation of particular associations, through parties, unions and the opportunity for universal suffrage, displaying dissonance with Rousseau's presumptions. Coutinho $(1991,2011)$ clarifies that this is how what is denominated in Gramscian thinking as civil society became established. That is, with the expansion of popular participation through parties, unions, etc., the expression of pluralism was no longer restricted to the individual, becoming an expression of collective subjects. Pluralism is no longer considered on the individual plane and only as an expression of individual differences that can support individualism and corporatism. It is also understood to refer to expressions of collective subjects. For this reason, it is necessary to observe that the fragmentation and pulverization of interests, encouraging individualism and corporatism, are evident obstacles to democracy, but so is despotism because it is an absolute denial of diversity - pluralism.

\subsection{Pluralism and Social Work}

Thus, pluralism as a reference in the realm of knowledge is the central point in our approach, which understands that pluralism is part of the sociopolitical dimension, of social projects and their values and goals. In terms of social work, we emphasize that the profession rose with an evident political dimension, given that it is an alternative to the bourgeois interests in support of workers needs at a given moment of capitalism. It can be said that it is an alternative that distinctly different from direct repression, as from the police, or from charity exercised by religious militancy, in face of the exacerbation of the expressions of the social question in the era of monopoly capitalism. As vastly promoted in the critical literature of the profession, social work is not a mere consequence of the qualification, by means of expansion of theoretical knowledge, of actions that utilize philanthropy and assistentialism to address expressions of the social question. The profession arose as one of the responses forged by the state with support from the Catholic Church in function of its project to recuperate Catholicism's ideological hegemony, which was placed in practice by the encyclicals Rerum Novarum of 1891 (presented by Pope Leão XIII) and Quadragésimo Anno of 1931 (of Pope Pio XI). This was a period in which the state became more present through systematic and continuous actions in social life. The state went beyond merely isolated and episodic responses to the outbreak of class antagonisms and the intensified organization of the working class, which sought to conquer better working and living conditions. That is, the state became more active in response to the exacerbated expressions of the social question, particularly in the period of passage of competitive capitalism to monopoly capitalism, which as Netto (2001, p. 19) explains, "raises to a higher level the totalizing system of contradictions that confer to the bourgeois order its fundamental traces of historic exploitation, alienation and "transitoryness"'. There was an expansion of social legislation in general in this period, triggered by capitalist logic, in the form of limited concessions that were understood to be necessary to respond to the growing worker struggles and protect capitalist domination from the most intense attacks of workers. This is where social policy is located, the realm of work that is fundamental to social workers. Aside from regional differences and highlighting that in Latin America the rise of the profession cannot be understood as a mere prolongation of its origin in Europe and the United States - due to the singularities in the distinct areas that correspond to the relations defined by capitalism - we can synthetically characterize the emergence of Latin American social work as a fruit of the conditions inherent to peripheral and dependent capitalism and its corresponding forms of expressions of the "social question". In Brazil, with the so-called Revolution of 1930 that led Getúlio Vargas to power, the state took the lead in supporting the expansion and consolidation of the existing industrial bases. Vargas sought the decline of power of the historic agricultural oligarchy by supporting the construction of bases for the rise of power of the industrial bourgeoisie in Brazil. Thus, the predominance of an economy sustained predominantly by agricultural exports declined in favor of a potential urban-industrial predominance. This process of capitalist expansion threatened the living and working conditions of those who headed to urban centers in search of survival without the resources needed for their essential needs. This generated social tensions that triggered the origin of Brazilian social work. Therefore, directing its actions at workers in function of their needs, but in keeping with the bourgeois interests, social work had its origin in Brazil, in the 1930s, supported by a set of knowledge aligned to conservative thinking, with an initial highlight for neo-thomism. Thus, 


\begin{abstract}
It can be said that for a long period the insertion of social work in social policies contributed to having certain working class interests be "refunctionalized" to support a capitalist logic - a professional alternative that acritically effectivated certain mediations needed for the maintenance of the social order, propagating and reinforcing the possibility for mutual collaboration between capital and labor. Therefore, it is not difficult, to understand why acritical and conservative thinking has been nearly unanimous in the social work profession for so long, nourishing moralizing explanations and positions in relation to social problems. And, even if we observe a change in this situation in the profession, we cannot affirm that it has been erradicated. When we mention the nearly unanimous existence of conservatism in the profession over the long term, we must remember the meaning of the Critical Movement in Social Work that was initiated in the mid 1960s, a process that, although it made some mistakes, certainly allowed important advances in the profession and brought it new theoretical supports, even substantially critical ones. (FORTI, 2013, p. 89).
\end{abstract}

Thus, the Latin American Movement for Reconceptualization of Social Work emerged in keeping with the context of the 1960s and marked an important critical review of the profession, influencing both its theoretical standards as well as professional exercise. It was a professional phenomenon in a heterogeneity of countries and regions that raised various questions about society and the injunctions placed on the work of social workers. It stimulated a distinct positioning, which was critical of social work and the demands made of it, and thus of the capitalist logic that historically dominated the profession, making viable different theoretical, ethical, technicaloperational and ideological-political conceptions. It thus materialized marked differences in our profession. In sum, it can be affirmed that it signified a professional phenomenon that, without having a unidimensional character, sought to establish bases that would allow going beyond traditional social work, which had been characterized by empiricist, palliative, reiterative and bureaucratized practices. It was a movement that, although it made mistakes, provided segments of the profession access to critical theoretical supports and as a result, supported alterations in the concepts adopted of man, society and state, generating a different theoretical reference for the profession. These theoretical references, in varying ways did not limit the analytical contents and parameters of the professionals solely to the bourgeois ideological horizon. Therefore,

Even if we understand that in this process there was no consistent theoretical criticism of the professional past, theoretical-practical elaborations developed from the process that broke with the conservative hegemony in the profession. A critical reference arose in relation to bourgeois society that was deepened and refined and that currently seeks to guarantee values that are aimed at legitimating practices that contribute to assuring working class interests, envisioning the possibility to construct a new social order. The logic of this order is not the contradiction between the human genre and the individual, or the primacy given to mercantilization in social life. (FORTI, 2013, p. 92).

Notwithstanding all that we have discussed about the profession, it is important to emphasize that if, based on this critical path that involved professional segments, we evaluate the scope of significant advances on both the intellectual and organizational planes of social work, we cannot affirm that its conservative history was eradicated. That is, while the origin of the profession helps understand the reason for the predominance or even the unanimous presence of uncritical, conservative and thinking in the profession, the fact that some professional segments took a critical direction does not imply that there was the traditional conservatism was eradicated. Today we find distinct positions, a pluralism and diversity in the profession, and this must be considered in the realm of professional education and in professional exercise. In particular, we must make these considerations if we intend to support the values and direction inherent to the critical project that, in the professional realm, we call the ethical-political project of social work. This means respectful consideration of the current Code of Professional Ethics of Social Workers, considering that it is an outstanding element, because it refers to the professional exercise, and to the curricular guidelines of the Brazilian Association for Education in Social Work of 1996 (ABEPSS, 2007), which are fundamental instruments for this project.

As responsibilities promoted in our profession, the premise of these curricular guidelines, in relation to the profile of the desired professional - a professional dotted with a critical, generalist intellectual and cultural education - is "the exercise of pluralism as an element particular to academic and professional life, which requires debate about the various theoretical trends that compose the production of the human and social sciences." (ORTIZ, 2013, p. 18). This premise, however, was changed by the Ministry of Education in the guidelines it approved in 2001, to the "exercise of pluralism as an element particular to academic and professional life." (ORTIZ, 2013, p. 18). Moreover, the current Code of Professional Ethics of Social Workers, has 11 principles that support (in articulation with each other) number 7: "Guarantee pluralism, through respect for 
existing democratic professional lines and their theoretical expressions and commitment to constant intellectual improvement" (FEDERAL COUNCIL OF SOCIAL WORK - CFESS, 1993, p. 3).

For this reason, we must be clear that the approach to pluralism in the dimension of the construction of knowledge - which as affirmed, does not exclude its possibility as a social and political phenomenon, and this is the focus of our discussion - cannot be confused with the absence of analytical parameters, or that is, with the possibility of acceptance of a junction without criteria of theoretical-philosophical lines that are not complementary. We cannot confuse pluralism with the fusion of different matrixes of thinking, indistinctively, or for the analysis or orientation of our professional action in the social reality. Moreover, the idea of relativism is not opportune, as if there was not a truth that could be sought but truths, which of course would be submitted to the possibilities and limits of subjects, given that they are constructed by them, signifying mere questions of angles of reasoning and conceptions that they determine.

This also reveals the inconsistency of considering as a lack of liberty the selection of a method as a privileged means in search of truth, which here signifies social reality. It is evident that this selection is based on the fact of evaluating it as the method that would best allow us to reveal the social reality, which would best allow us to seek approximation with truth. This is because, for us, there is truth, we evaluate its existence, its historic formation, and the possibility for us to approximate it through research, constructing various forms of knowledge. We are not saying that it is possible to grasp social reality in all its dimensions. We know that social reality is complex, dynamic and infinitely rich, but to say this does not mean that we cannot desire to come increasingly closer to it. It is also not for us to justify skepticism, which concludes that there is no truth, affirming that the alternative to truth is a mere fruit of intersubjective consensus, effectivated by means of preestablished criteria, for example. This allows us to understand that the social reality or the social being can be captured by means of the movement that allows us, through reason, to extract from objective processes their intrinsic legality. Therefore, instead of seeking the idea in the idea, making the object analyzed a mere theoretical construction, we reconstruct the process of this object, which is historically given, seeking the idea in the very object investigated. In this respect Tonet (1995 p. 48) clarifies that:

\begin{abstract}
An ontological approach to the question of knowledge does not begin with the self-examination of reason [...] but seeks the genesis and the direction of knowledge in the complex act that establishes the social being. The being of knowledge is only revealed at its maximum depth in its ontological-practical function. In the founding act of the social being, which is labor, it discovers that this is constituted by two poles that compose an inseparable unity, the pole of subjectivity and the pole of objectivity, with praxis the moment of mediation between one and another [...] The transformation of the world, for the resolution of the problems triggered by human needs, requires, in various degrees, the capture, by consciousness of objective determinations and of causal connections of which the world is composed.
\end{abstract}

All of this reveals that from our perspective reality exists and is not the undiscriminating combination of different matrixes of theoretical-philosophical thinking that allow us to attain it, as if this would provide us the best, most efficient way to grasp reality. When we refer to pluralism we are not focusing on relativism in the analysis of social phenomenon, nor relativism and or eclecticism in the means of grasping these phenomenon. Nor are we suggesting the possibility of neutrality of scholars in the fields related to the human world or the inviability of the debate of distinct positions. To the contrary, we must observe that:

Pluralism in the field of the natural or social sciences [...] is synonymous to opening to the different, of respect for the position of others, considering that this position, by warning us of our errors and limits, and by providing suggestions, is necessary to the development of our own position, and in general, of science [...] It is a position of opening of those who judge that tolerance is essential to the progress of science, to the enrichment of our own position [...] with the certainty that for each question there is only one globally true response. (COUTINHO, 1991, p.14).

We understand this discussion is important in our professional realm, as we said at the beginning. This is quite clear, for example, when we constantly confront professional discourses that affirm a tie with a certain line of critical thinking and with the critical professional project, which, in the professional realm, is denominated the ethical-political project of social work. Nevertheless we do not observe a correspondence in professional action or a search for this, in the face of this affirmation. We say this, supported by lengthy professional experience, as a social worker in the field of teaching and in other realms of social policy, by the results of our academic studies and from other studies, particularly in graduate studies in social work (FORTI, 2016; FORTI; GUERRA, 2015). Of course we cannot ignore impediments imposed by working conditions for professionals in 
the field, although we can identify, but on a significantly smaller scale, some professional experiences that are compatible with the critical orientation proposed by this ethical-political project.

Thus, we have countless questions about this theme, which we raise here in part, and that we hope will be increasingly expanded in our professional field. From what we know, it is quite probable that a profession exercised in a democratic social context comports different theoretical-philosophical conceptions in its theoreticalpractical foundations and expressions. Nevertheless, this does not imply it is exempt from analytical parameters and or action. Therefore, it is essential that we observe to what degree we are attentive to the fact that pluralism, which presents itself as one of the main fundaments of our Professional Code of Ethics and as a guide to professional education and exercise, cannot be confused with eclecticism, that is, with the possibility of indiscriminately combining and even fusing distinctive lines of thought. This would mean defending neutrality in the field of the sciences that support social work, as if the selection of a given reference was exempt from implications in social life and would signify only a mere choice among equivalents, without this representing any

\section{The idea that the adhesion to}

\section{and the consequent effort for}

the materialization of the

principles and values that

constitute the curricular

guidelines of ABEPSS, the

current Professional Code of

Ethic and the critical

professional project, does not

require adequate and

compatible knowledge,

interferes directly in the

question of pluralism [...] consequence for professionals, for those they serve, for the profession and for society in general. It is worth emphasizing that our current Professional Code of Ethics mentions respect for the different professional currents, but does not fail to clarify that this respect is due to democratic theoretical-philosophical matrixes and does not consider them to be equivalent. We must note that all the fundamental principles, even those that refer to pluralism, compose a framework that expresses values and orientation to the professional horizon in support of a critical contribution that envisions the possibility of going beyond the given social order. Moreover, by referring to pluralism we seek to clarify that this aspect does not accept dogmatism or sectarianism, that is, it does not accept the perspective that subjects can be intransigent towards points of view that are different from their own, by believing that they detain the truth, without recognizing the importance of seeking to confirm and or improve the understanding of this truth through the debate of ideas with others.

In the realm of the sciences, pluralism is synonymous with opening to the different, given that tolerance to the progress of science is judged to be fundamental to the enrichment of one's own position, even knowing that the truth does not signify an idea constructed by subjects, but something that they must grasp, using compatible means.

The relation of these arguments with our professional field can be easily understood if we consider, for example, that despite significant theoretical and organizational advances, conservatism and other errors in the professional daily work of social workers are recurrent and can represent important harm to the users of institutions, the profession and society. It is not peculiar for us to mention that there are constant professional references that attribute the difficulties experienced in the daily work of professionals to the current critical ethical-political project. There are those who allege that this project would only have meaning and could only be defended if we had better working conditions, as if their existence is not related precisely to professional and social forces critical of the ruling order and aimed at confronting the obstacles to democratic objectivations, therefore, aimed at countering the degradation of working conditions that support capitalist expansion (FORTI, 2016).

It must also be kept in mind, that despite the advances mentioned, there can be struggle in support of individual interests and or of particular groups that lead to disparagement of the debate, to disparagement of those who have different ideas, as if they represented a danger, a mere adversary that must be refuted or eliminated, even if they belong to the same school of thought. In this respect, we emphasize that

mainly in a competitive society such as ours, where alienation is characteristic, this can occur by mere competition, using the alibi that there is an essential theoretical-political difference; that is, disqualify the other to win the debate and attain the desired position or any other type of individual interest or that of a particular group. It is as if commitment to the truth is not necessary, but what is necessary is make effective a supposed individual success or that of particular groups in an exercise that is commonly considered politically legitimate. (FORTI, 2013, p. 95). 
The idea that the adhesion to and the consequent effort for the materialization of the principles and values that constitute the curricular guidelines of ABEPSS, the current Professional Code of Ethic and the critical professional project, does not require adequate and compatible knowledge, interferes directly in the question of pluralism, given that it is a theoretical-philosophical aspect that, as we said, supposes the professional capacity to not fall into relativism, eclecticism and neutrality and or into the reductionism typical to doctrinaire and sectarian positions. It can be said that the comprehension and incorporation of these principles and values also presupposes much more than a mere will or adhesion to propaganda that, as a type of mantra supposes it is sufficient to make the idea a reality.

This discussion is important to the supervision of internships as part of their professional education. That is, this supervision must provide interns with critical and appropriate knowledge considering the foundations and opportunities for action of the profession. It must expose them to a debate among the various positions at the heart of the profession, revealing the different conceptions of man and society, and therefore, the distinct lines of thinking that are also present in social work, delineating and giving meaning to the work of professional. Supervision is essential to the education of social workers and must be provided by professionals in the field. This is determined in article $5^{\circ}$ of Law 8.662, of 7 June, 1993, which regulates the profession, and is assured in the current Professional Code of Ethics of Social Workers, in its article $4^{\circ}$, letter "e", that prohibits: "permitting or exercising the supervision of a social work student in public or private institutions that do not have a social worker on staff who directly accompanies the student intern" (CFESS, 1993, p. 5).

The critical literature of the profession clearly expresses that the society in which we live is composed of distinct social forces that maintain contrasting and even antagonistic projects. This has repercussions in the professional realm. Within the profession we find projects based on different theoretical-philosophical, methodological and technical-operational conceptions, which requires that we study and identify them, develop critical knowledge and conduct permanent debate. This is an important argument about which supervisors of interns (those from their school and from the field of the internship) must provide essential guidance. The interns must have command of this debate, so that they can competently conduct their activities, establish conscious goals and options for action that are compatible with them, and so that they can evaluate the direction taken in the daily work of the institution where they conduct their internship and by its future professionals.

Thus, the debate about pluralism is essential to social work, especially when we consider qualified professional education, as proposed by ABEPSS and when we observe that current threats increase the difficulties to its implementation. As we said, we are experiencing a period in Brazilian history in which even the obvious must be expressed, given the discourses and practices that intend to obfuscate reality. They may denominate certain social phenomenon in a different mode - which can also be seen in the professional realm, because as we know, even if they arise in different manners, professional projects maintain links with social projects. An educational policy is being organized that appears to affirm that the right to higher education can be democratized by providing an increasingly greater number of openings at private educational institutions and distance courses. This belief, in addition to not presenting education as a universal right, certainly goes against the possibility of assuring what we propose in this debate for our field, which is the development of generalist and critical professionals as determined by the guidelines of the Brazilian Association of Education and Research in Social Work (ABEPSS, 2007, p. 227).

This is indicated by the fact that of Brazil's 32,878 undergraduate courses offered by institutions of higher education, only $12.6 \%$ are in public institutions and $87.4 \%$, are in private institutions. Among the undergraduate programs in social work, in 2014 there were only 24 distance courses and 401 classroom courses, but the number of students concluding the distance courses was higher. We had 13,343 people concluding the courses at 24 institutions of distance learning and 12,129 students completing the 401 classroom courses (MARTINS, 2016).

\section{Final considerations}

The understanding of reality as a synthesis of multiple determinations (which is a concept used repeatedly in the critical literature of social work) presupposes understanding diversity as a category that is part of our reality, contrary to attempts to portray illogical homogenizations or hierarchizations. Therefore, to not see diversity as an obstacle but as an expression of real social life allows us to value the exchange of knowledge in search of substantive understanding. Debate among different positions, distinct types of knowledge, seeking an intellectual enrichment that approximates us to essential knowledge, requires that we go beyond reductionisms and prejudices and idealized attempts at conciliation and homogenization that fog reality and do not allow historic ontological knowledge. 
Meanwhile, although professional conservatism has not been eradicated, and may even be expanding, there are consistent criticisms that help Brazilian social work to maintain a professional project in which pluralism and professional competence continue to be references. The ethical-political dimension shows that a critical segment within the profession is opposed to individualist elitist values based on exploitation and competition. Ever since the reconceptualization movement in social work, a critical professional project has been developed that defends radically democratic values, guidelines and goals - which are nearly always referred to as the ethical-political project of Brazilian social work. It affirms professional goals that are in keeping with values articulated to workers interests. Therefore, grasping the fundaments, the social direction and the purpose of the critical professional project and the Professional Code of Ethics, in an interventive profession such as social work, means grasping the need for a continuing search for intellectual and professional improvement. It understands that the scope of the professional condition, both analytical and interventive, should provide social workers the competence to professionally confront inappropriate socio-institutional positions and demands, such as conservative ones that affront democratic values aligned to the interests of those who live from their own work as well as positions that ignore liberty, human rights and pluralism as an expression of real life. In sum, we defend a professional project that is incompatible with illogical hierarchies and prejudices, while maintaining respect for the different existing democratic professional lines and their theoretical-practical expressions; and an uninterrupted search for professional improvement. That is, our position reveals elements that do not correspond to relativism, to dogmatism or sectarianism, it cannot be confused with eclecticism or neutrality, and cannot involve a theoretical-critical inconsistency or a lack of respect for the hegemonies legitimately conquered in the professional field.

\section{References}

ASSOCIAÇÃO BRASILEIRA DE ENSINO E PESQUISA EM SERVIÇO SOCIAL. Diretrizes Curriculares do Curso de Serviço Social: sobre o processo de implementação. Temporalis, São Luís (MA), v. 7, n. 14, jul./dez. 2007.

CONSELHO FEDERAL DE SERVIÇO SOCIAL. Código de Ética Profissional do Assistente Social e Lei 8662/93 que regulamenta a profissão do Assistente Social. Brasília: CFESS, 1993. Disponível em: <http://www.cfess.org.br/arquivos/CEP_1993.pdf>. Acesso em: 12 fev. 2017.

COUTINHO, C. N. Pluralismo: dimensões teóricas e políticas. Cadernos ABESS, São Paulo, Cortez, n. 4, p. 5-17, 1991. . De Rousseau a Gramsci: ensaios de teoria política. São Paulo: Boitempo, 2011.

FORTI, V. L. Ética, crime e loucura: reflexões sobre a dimensão ética no trabalho profissional. 4. ed. Rio de Janeiro: Lumen Juris, 2016. . Considerações sobre o sétimo princípio fundamental do código de ética dos assistentes sociais: o pluralismo em debate. In:

CONSELHO REGIONAL DE SERVIÇO SOCIAL-RJ. (Org.). Projeto Ético-Politico e exercício profissional em Serviço Social: os princípios do código de ética articulados à atuação crítica de assistentes sociais. Rio de Janeiro: CRESS, 2013. p. 87-99.

; GUERRA, Y. (Org.). Projeto Ético-Político do Serviço Social: contribuições à sua crítica. Rio de Janeiro: Lumen Juris, 2015.

MARTINS, T. S. A centralidade da ética na formação profissional do assistente social: um estudo na graduação em Serviço Social em Teófilo Otoni-MG. 2016. Dissertação (Mestrado em Serviço Social) - Programa de Pós-Graduação em Serviço Social, Universidade do Estado do Rio de Janeiro, Rio de Janeiro, 2016.

NETTO, J. P. Capitalismo monopolista e Serviço Social. 3. ed. São Paulo: Cortez, 2001.

ORTIZ, F. G. Notas sobre as Diretrizes Curriculares: avanços, impasses e desafios. In: GUERRA, Y.; LEITE, J. L.; ORTIZ, F. G. (Org.). Temas contemporâneos: o Serviço Social em foco. São Paulo: Outras Expressões, 2013. p. 11-31.

TONET, I. Pluralismo metodológico: um falso caminho. Serviço Social e Sociedade, São Paulo, Cortez, v. 16, n. 48, p. 35-57, ago. 1995.

Valeria Lucilia Forti

vforti17@gmail.com

Doutorado em Serviço Social pela Universidade Federal do Rio de Janeiro (UFRJ)

Professora dos cursos de Graduação e Pós-Graduação em Serviço Social da Universidade Estadual do Rio de Janeiro (UERJ)

\section{UERJ}

Rua São Francisco Xavier, 524, $8^{\circ}$ andar, sala 8031 - Maracanã

Rio de Janeiro - Rio de Janeiro - Brasil

CEP: $20.550-900$ 